\title{
Orchid exploration in Tanjung Peropa Wildlife Reserves for Kendari Botanic Gardens collection, Indonesia
}

\author{
SRI HARTINI", POPI APRILIANTI" \\ Research Center for Plant Conservation and Botanic Gardens, Indonesian Institute of Sciences. Jl. Ir. H. Juanda 13, Bogor 16122, West Java, Indonesia. \\ Tel./fax.: +62-251-8322187, `email: srihartinikrb@gmail.com
}

Manuscript received: 14 January 2019. Revision accepted: 27 April 2020.

\begin{abstract}
Hartini S, Aprilianti P. 2020. Orchid exploration in Tanjung Peropa Wildlife Reserves for Kendari Botanic Gardens collection, Indonesia. Biodiversitas 21: 2244-2250. Tanjung Peropa Wildlife Reserve (Tanjung Peropa WR) is one of the conservation area in Southeast Sulawesi Province, Indonesia. The inventory of orchid in this area is still limited and Kendari Botanic Garden (Kendari BG) need to collect the orchids from this location. Orchid diversity inventory and exploration had been carried out on March 26- April 12, 2019, in Tanjung Peropa WR and collecting them as an ex-situ conservation effort in order to enrich Kendari BG plant collection. The specimen was collected by using explorative method at 5 locations in Tanjung Peropa WR. The result showed that there were 10 epiphytic orchids found of Aerides, Cymbidium, Dendrobium, Grammatophyllum, Liparis, Pomatocalpa, and Thrixspermum. Also, there were 5 terrestrial orchids of Corymborkis, Eulophia, Nervilia, Phaius, and Tropidia. The orchid species were found in the area between $25-110 \mathrm{~m}$ above sea level (asl), with temperature $27-31^{\circ} \mathrm{C}$, humidity $75-80 \%$, soil acidity $5.0-6.0$, soil humidity $80-90 \%$, and canopy dense between $60-80 \%$. Kendari BG has collected 34 species of orchid from Southeast Sulawesi, with 25 species of epiphytic and 9 species of terrestrial orchids.
\end{abstract}

Keywords: Exploration, Kendari Botanic Gardens, orchids, Southeast Sulawesi

\section{INTRODUCTION}

The Indonesian Botanic Gardens (IBG) has responsibility in implementing plant conservation and research activities in Indonesia. There are five botanic gardens under Indonesian Institute of Sciences (LIPI), they are Bogor Botanic Gardens, Cibinong Botanic Gardens, Cibodas Botanic Gardens, Purwodadi Botanic Gardens, and Eka Karya Bali Botanic Gardens, but there is only $21 \%$ of Indonesian threatened plant species that have been conserved ex situ in IBG (Widyatmoko and Risna 2017). With this condition, there is an urgent of developing new botanical gardens. Based on Presidential Decree No. 93/2011, it is IBG as representative of LIPI that has task to develop a national master plan of botanic gardens development. Since 2005, many local botanic gardens (LBG) have been developed and managed by provincial and district governments and universities (Purnomo et al. 2015). By the end of 2018, there are 32 LBG under provincial and 2 LBG under universities (P2KTKR 2018).

According to Whitten et al. (2002), Sulawesi contains the largest areas of ultrabasic bedrock in the world, altogether about $8000 \mathrm{~km}^{2}$. Moreover, Vermeulen and O'Byrne (2011) stated that a typical lowland ultrabasic forest is rather open with low stunted trees. This indicates that this kind of soil is infertile and have little waterretaining capacity and notoriously deficient in exchangeable nutrients, including the trace elements. This condition is getting severe with toxic concentration of heavy metals that often occurs. This type of environment then triggers adaptation and speciation amongst plants and animals that lived there.
South East Sulawesi (SE Sulawesi) is one of the ultrabasic area, which is rich in high-value minerals. Kendari Botanic Gardens (Kendari BG) is one of LBG and located in Southeast Sulawesi. Its management is under Environmental Agency of SE Sulawesi Province. Forest Zone with Special Purpose with 96 ha areas was established as Kendari BG by the Ministry of Environment and Forestry Number SK No.187/MenLHK/Setjen/ PKTL.0/3/2016. This area was built for research, development, and environmental education and this BG has Ultrabasic Plants theme for its plant collection. The establishment as ultrabasic plant conservation area is a symbol of Sulawesi floras that have the biggest areas of ultrabasic in Indonesia. Those plants conserved to be known their potential uses for humans (Febrianti and Astuti 2019).

As we know, Sulawesi is one of the largest island in Indonesia, and the fourth largest in Southeast Asia. It has been known that Sulawesi occupies a unique position, as it straddles the "Wallace Line" (Vermeulen and O'Byrne 2011). Thomas and Schuiteman (2002), recorded 548 orchid species on the island, and until now accounts of orchid of SE Sulawesi have been very limited. Recently, orchid species are threatened by forest degradation and over-exploitation. This condition is getting severe with mining activities in few parts of SE Sulawesi. It will change the flora composition around the area, especially the reduction of particular tree species, which will decline number of orchid species in nature (Lestari and Santoso 2011). Therefore, ex-situ conservation must be done, and also the potential uses of orchid as ornamental plant can be developed for economic purpose. 
Sulistiarini (2008) reported 91 orchid species in Wawonii Island, SE Sulawesi, in which 36 species were new records and four were endemic species to Sulawesi. Also, there was report of the orchid biodiversity in Mekongga, which wrote 37 species found, including four species endemic to Sulawesi, some new records, and some new species, for example, Dendrobium tinukariensis (Sulistiarini et al. 2017). Another paper described the orchid species in Lamedai Nature Reserve, Kolaka, and mentioned that there were 27 orchid species in the area, which consisted of 25 epiphytic and 2 terrestrial species (Lestari and Santoso 2011). Tanjung Peropa wildlife Reserves as one of in situ conservation areas is threatened by habitat degradation, meanwhile, the orchid species data in this area are still unknown yet. The aim of this research was to study the orchid diversity in Tanjung Peropa Wildlife Reserves and the data will be valuable information to complete the orchid diversity data of SE Sulawesi. Also, the orchid will be collected ex-situ in order to enrich the KBG orchid collection, which potential for research and commercial uses.

\section{MATERIALS AND METHODS}

\section{Research sites}

The Tanjung Peropa Wildlife Reserve (Tanjung Peropa WR) is one of the in-situ conservation areas in South Konawe District, Southeast Sulawesi Province, Indonesia by the Ministry of Forestry number 393/Kpts-VII/1986 date 23 December 1986 (Figure 1). Administratively, it is included in Konawe Selatan District and it covers 38,937 hectares area. Tanjung Peropa WR is at 0-900 $\mathrm{m}$ above sea level (asl), with flat, hilly, and mountainous topography, with slope until 45\% (Indonesian Forest 2015; Mustari
2017). Flora exploration was conducted on $26^{\text {th }}$ March- $12^{\text {th }}$ April 2019 with 5 (five) locations visited: Moramo waterfalls (location 1.25-105 m asl), Amolengu Village (location 2.25-45 m asl), Ulunese Village (location 3.0-10 $\mathrm{m}$ asl), Langgapulu Village (location 4.25-35 $\mathrm{m}$ asl), and Batu Putih (location 5.10-45 m asl.) (Figure 1).

The latitude and longitude of locations were between $\mathrm{S}$ $04^{\circ} 13^{\prime} 26^{\prime \prime}$ to $\mathrm{S} 04^{\circ} 24^{\prime} 9^{\prime \prime}$ and E $122^{\circ} 44^{\prime} 10^{\prime \prime}$ to $122^{\circ} 49^{\prime} 53^{\prime \prime}$. The canopy dense between $60-80 \%$ and temperature during the activity was $27-31^{\circ} \mathrm{C}$ with relative humidity (RH) during the day ranged from $80-90 \%$. Soil acidity $(\mathrm{pH})$ was about 5-6 and soil humidity $80-90 \%$.

\section{Methods}

The exploration activity was collecting orchids by using explorative methods along the forest path that usually used by local people or making new track (Hidayat et al. 2017). Observation, documentation, and collection were made at all locations visited. The data included name of the species, number of the specimen for each species, location, and microclimate for each location were documented. Photographs and living collections were taken for identification and collecting process. Identification was carried out by observing and taking notes to plant morphology, including leaves, stems, roots, and flowers. Puspitaningtyas (2019) stated that most orchid species without flower can be identified only in its genus, but some species with specific vegetative character can be identified to species level even without flower. Scientific orchid books also used for identifying, such as Comber (1990), Seidenfaden and Wood (1992), and Comber (2001). The valid name of orchid species referred to The Plant List (2013). All of the orchid species found were collected to be planted in Kendari Botanic Gardens for ex-situ conservation program.

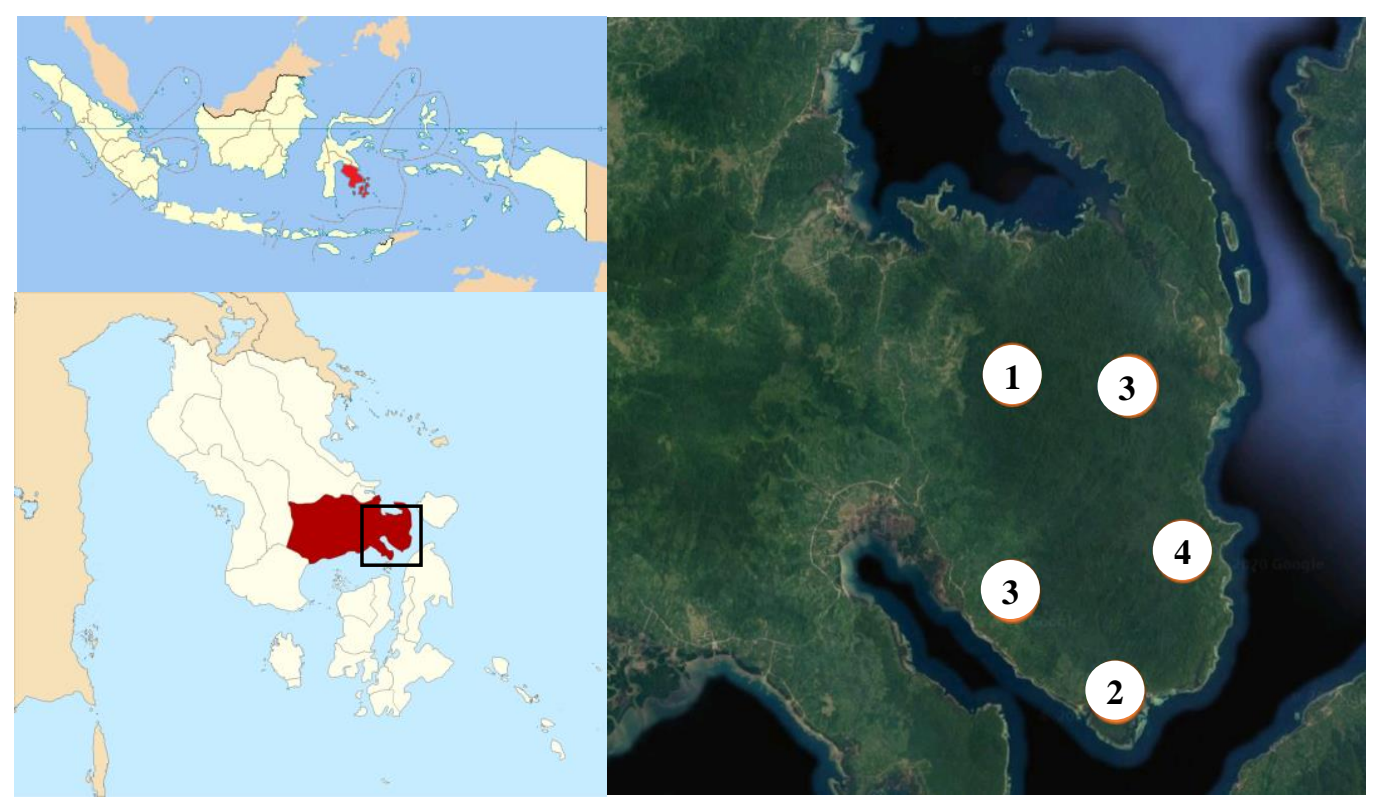

Figure 1. Map of research site at South Konawe District, Southeast Sulawesi Province, Indonesia. 1. Moramo Waterfalls, Sumber Sari Village, Moramo Sub-district, 2. Amolengu Village, Sub-district Kolono, 3. Ulunese Village, Sub-district East-Kolono, 4. Langgapulu Village, Sub-district East-Kolono, 5. Batu Putih Village, Sub-district Moramo 
Terrestrial orchid species handling in Kendari BG were done by planting them in polybags, which contented with soil of Kendari BG and compost, without throwing away the soil from the forest that used to cover the roots. Collection then placed in the plastic house inside the paranet house. It needs only once a week for watering the collection, because the water vapor as the effect of the plastic house was enough for watering the plant. Meanwhile, the epiphytic orchids were placed in the pots that content chopped ferns and wood charcoal or stuck to the piece of fern. These collections were laid inside paranet house. The watering was carried out in the morning and evening. When the plant has grown adaptively and generated new leaves, then it is ready to be planted in the orchid house.

\section{RESULTS AND DISCUSSION}

There were 15 species of orchid found in Tanjung Peropa WR, 10 species of epiphytes from seven genera, they were Aerides, Cymbidium, Dendrobium, Grammatophyllum, Liparis, Pomatocalpa, and Thrixspermum. And five species of terrestrial orchids found from five genera have been identified, they were Corymborkis, Eulophia, Nervilia, Phaius, and Tropidia (Table 1). The highest number of orchid species found was near Moramo Waterfalls (Location 1) (Figure 2) with 12 species, followed by location 3 and 5 (three species), and the least was location 2 and 4 (two species).

Location 1 had many big trees, such as Pometia pinnata J.R.Forst. \& G.Forst., Palaquium spp., Garcinia spp., Pangium edule Reinw., Artocarpus elasticus Reinw. ex
Blume, Diospyros pilosanthera Blanco with dense canopy coverage. Elastostema sp., Aglaonema simplex (Blume) Blume, Phrynium sp., and Schismatoglottis calyptrata (Roxb.) Zoll. \& Moritzi were dominant species as shrubs. Air and soil humidity were also high and this condition is suitable for orchid to grow well. Other sites had low orchid diversity, this could be caused by orchid exploitation by people around the forest and also the habitat destruction, such as road construction to make access to other districts.

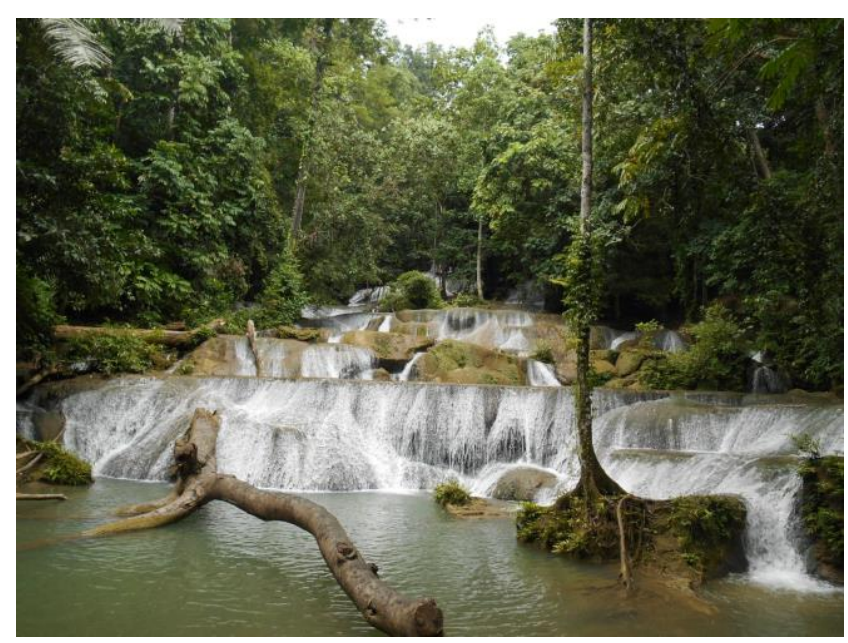

Figure 2. Moramo Waterfalls in Tanjung Peropa Wildlife Reserve, Southeast Sulawesi, Indonesia

Table 1. List of orchid species found in Tanjung Peropa Wildlife Reserve, Southeast Sulawesi, Indonesia

\begin{tabular}{|c|c|c|c|c|c|c|c|}
\hline \multirow{2}{*}{ Orchid species } & \multirow{2}{*}{ Habitus } & \multirow{2}{*}{$\begin{array}{l}\text { Number of } \\
\text { specimens }\end{array}$} & \multicolumn{5}{|c|}{ Research site (location) } \\
\hline & & & 1 & 2 & 3 & 4 & 5 \\
\hline Aerides odorata Lour. & Ep. & 4 & $\mathrm{x}$ & & & & \\
\hline Cymbidium finlaysonianum Lindl. & Ep. & 4 & $\mathrm{x}$ & & & & \\
\hline Cymbidium bicolor Lindl. & Ep. & 2 & $\mathrm{x}$ & & & & \\
\hline Dendrobium crumenatum $\mathrm{Sw}$. & Ep. & 3 & $\mathrm{x}$ & & $\mathrm{x}$ & $\mathrm{x}$ & $\mathrm{x}$ \\
\hline Dendrobium sp. & Ep. & 1 & $\mathrm{x}$ & & & & \\
\hline Grammatophyllum scriptum (L.) Blume & Ep. & 3 & $\mathrm{x}$ & & & & \\
\hline Liparis condylobulbon Rchb.f. & Ep. & 2 & $\mathrm{x}$ & & & & \\
\hline Liparis parviflora (Blume) Lindl. & Ep. & 1 & $\mathrm{x}$ & & & & \\
\hline Pomatocalpa spicatum Breda & Ep. & 4 & $\mathrm{x}$ & & & & \\
\hline Thrixspermum centipeda Lour. & Ep. & 1 & & & & & $\mathrm{X}$ \\
\hline Corymborkis veratrifolia (Reinw.) Blume & Tr. & 4 & $\mathrm{x}$ & & $\mathrm{x}$ & & \\
\hline Eulophia spectabilis (Dennst.) Suresh & Tr. & 4 & & $\mathrm{x}$ & $\mathrm{x}$ & & \\
\hline Nervilia concolor (Blume) Schltr. & Tr. & 5 & $\mathrm{x}$ & & & $\mathrm{x}$ & $\mathrm{x}$ \\
\hline Phaius tankervilleae (Banks ex I'Heritage) Blume & Tr. & 1 & & $\mathrm{x}$ & & & \\
\hline Tropidia angulosa (Lindl.) Blume & Tr. & 5 & $\mathrm{x}$ & & & & \\
\hline Total species & 15 & & 12 & 2 & 3 & 2 & 3 \\
\hline
\end{tabular}

Note: x: exist. Ep.: Epiphytic, Tr.: Terrestrial. 1. Moramo Waterfalls, Sumber Sari Village, Moramo Sub-district, 2. Amolengu Village, Kolono Sub-district, 3. Ulunese Village, East-Kolono Sub-district, 4. Langgapulu Village, East-Kolono Sub-district, 5. Batu Putih Village, Moramo Sub-district 


\section{Epiphytic orchids}

Ten species of epiphytic orchids found in a very limited number of specimen (1-4 specimens for each species) (Table 1). Two species of Cymbidium found in Moramo Waterfalls, namely Cymbidium bicolor Lindl. and Cymbidium finlaysonianum Lindl. (Table 1; Figure 3.B and 3.C). These two species distributed in a similar area, mostly in Java, Sumatera, Borneo, Sulawesi, and the Philippines, and also widespread in lowlands areas near the sea and potential as ornamental plant (Seidenfaden and Wood 1992). Cymbidium bicolor has flowers arranged in hanging inflorescence, with 5-13 scented red yellow-whitish flowers, meanwhile $C$. finlaysonianum has red maroon flowers and the commonest Cymbidium of lowlands. Cymbidium finlaysonianum also found in Wawonii Island (Sulistiarini 2008) and Lamedai Nature Reserve (SE Sulawesi) with more individuals found (21 individuals) (Lestari and Santoso 2011). Other exploration activities also noted that in Polewali Mandar (West Sulawesi) and Bantimurung Bulusaraung National Park (South Sulawesi) there was C. finlaysonianum along with Aerides odorata Lour., Dendrobium crumenatum Sw., Liparis condylobulbon Rchb.f., and Liparis parviflora (Blume) Lindl. (Puspitaningtyas 2017; Puspitaningtyas 2019; Rahayu and Putri 2019).

Aerides odorata is one of the common orchid, well known as "tiger nail" orchid (Figure 3.A). This species found only in Moramo waterfall, altitude is $25-105 \mathrm{~m}$ asl, with four specimens. Aerides odorata grows on lowland forest from 0-400 $\mathrm{m}$ asl and often near the sea (Seidenfaden and Wood 1992). This species distributes in China, India to Southeast Asia and can survive in the long dry season, even it is flowering in that season. This nail tiger orchid has axillary inflorescence with 25 scented flowers, white base color and purple spot/dot in the corner of the petals. This unique species is potential as ornamental and also as medicinal plant which content bioactive compounds ethyl acetate and methanol as the source of anticancer drugs (Katta et al. 2019).

One of the fascinating orchids is Grammatophyllum scriptum (Figure 3.D). This orchid was found attached at the top of a large tree, as it collected from the terminal part of the fallen branch. This species is extraordinary because it has large size and showy flowers with long inflorescence, which can bear up to 40 flowers. It is known as "tiger orchid", refer to brown dots on the tepals. It was found near the Moramo waterfall with 25-105 m asl (Table 1). Based on Handoyo and Prasetya (2012), G. scriptum grows on mangrove and lowland forest as an epiphyte in the area with full sun exposure. This species is distributed from Sulawesi, Kalimantan, Maluku, Papua up to Pacific Islands.

Liparis condylobulbon and $L$. parviflora were also found in Moramo Waterfalls. Liparis condylobulbon is an orchid species with a very minute flower (flower size 3-6 $\mathrm{mm})$ and distributed from Burma through Southeast Asia to Australia up to Solomon Islands (O’Byrne 1994). Moramo Waterfall is a suitable habitat for this orchid, since it was found living in the branch of short tree in the humid area. Based on O'Byrne (1994), L. condylobulbon has smooth leaf-green with swollen pseudobulb at the base. A singleflower spike emerges from narrow green leaves and bears up to 50 crowded small yellow flowers. The sepals and petals are green and curve backward, while the lip is dull orange to brown (Figure 3.E).

Pomatocalpa spicatum was found in Moramo Waterfalls. Other papers mention that this orchid was also found in Rawa Aopa Watumohai National Park, Southeast Sulawesi (Indrawati et al. 2017), and Bantimurung Bulusaraung National Park, South Sulawesi (Puspitaningtyas 2017). This is the most widespread species among its genera, from India, Philippines, Sumatera, Borneo, Sulawesi to Maluku (Handoyo and Prasetya 2012; Watthana and Pedersen 2006). This species is a short-stemmed monopodial orchid with 3-10 linearoblanceolate leathery leaves and the unbranched inflorescences penetrate the leaf sheats. They have short peduncle with 10-60 synchronously open small flowers. This species is potential to be an ornamental plant, since it has yellow, streaked, and purplish-brown blotched sepals and petals (Figure 3.F).

Dendrobium crumenatum, known as pigeon orchid, found in four locations. This species is cosmopolitan orchid, distributed in Seychelles, Taiwan, India (Andaman and Nicobar Islands), Sri Lanka, Cambodia, Laos, Myanmar, Thailand, Vietnam, Sumatera, Java, Borneo, Sulawesi, Moluccas and Philippines, Papua up to Hawaii (Ram et al. 2015). It was found in the open space area with direct sunlight exposure, in the lowland forest. This species has white sepals and petals, half yellow lip, with specific odor, arising from distal leafless part of the stem. Dendrobium crumenatum is potential as medicinal plant as eardrop and elephant foot disease (roots and pseudobulbs) (Lawler 1984; Sulistiarini and Mahyar 2003).

\section{Terrestrial orchids}

There were five species of terrestrial orchids found in Tanjung Peropa WR, namely Corymborkis veratrifolia (Reinw.) Blume, Eulophia spectabilis (Dennst.) Suresh, Nervilia concolor (Blume) Schltr., Phaius tankervilleae (Banks ex I'Heritage) Blume, and Tropidia angulosa (Lindl.) Blume (Table 1; Figure 4). They found on the forest floor which has relatively dense canopy in the very humid area. All of the research areas visited had terrestrial orchids (Table 1). Most of the place had humid condition and near the sea. Those species grew in small groups and spread.

Corymborkis veratrifolia and E. spectabilis also found in Rawa Aopa Watumohai National Park (Indrawati et al. 2017) and Waonii Island - SE Sulawesi (Sulistiarini 2008), and also in Polewali Mandar, West Sulawesi (Puspitaningtyas 2019) and Bantimurung Bulusaraung National Park, South Sulawesi (Puspitaningtyas 2017; Rahayu and Putri 2019). These orchids have a wide distribution area in Sulawesi. Corymborkis veratrifolia found in Moramo Waterfalls and Ulunesse Village (Table 1; Figure 4.A). This species distributed in Indochina throughout Indonesia to New Guinea, Australia to Pacific Islands (Seidenfaden and Wood 1992). It is large and unbranched plant, meanwhile, inflorescences branching 
with short stem, flowers are facing varied directions, 20-30 $\mathrm{mm}$ long, with white petals and pale green sepals. It was one of the tough species and very diverse in the shape and colors of the flowers because the habitats ranging from 0 $1850 \mathrm{~m}$ asl (Puspitaningtyas 2019). In Tanjung Peropa forest, $C$. veratrifolia grows in the very shaded place and dense coverage. Meanwhile, in Ulunese Village, it grows near the sea, in the open and flat area. The forest is quite open and the dominant tree species was Corypha utan. Based on Comber (2001), this orchid prefers the shaded and humid area, mostly in the very rich nutrition soil, and also in the little dry area, even the soil fertility is decreasing.

Nervilia concolor (Figure 4.B) found in three locations, Moramo Waterfalls, Langgapulu, and Batu Putih Villages. This indicated that the species was quite common in Tanjung Peropa WR. Its habitat was in the humid area with dense canopy, but in general $N$. concolor can grow in the open area, dense forest, roadside, or event in the half shade savanah. Batu Putih Village had the very dense forest with many big trees. Forest floor was humid, dominated by Zingiberaceae, like Etlingera spp., Alpinia sp., and Curcuma sp. This plant found in small colony and based on Sharma et al. (2013), this terrestrial species is living in colony and the pseudobulbs growing within different phases between generative and vegetative phases. Nervilia concolor is unique because it has heart-shaped leaves, with wavy margins. Leaf is glabrous and green sometimes with chocolate brown blotches. The inflorescence is $35 \mathrm{~cm}$ in height with 4-10 white-yellowish green flowers, not fully open, and emerging from bulbs underground (Puspitaningtyas 2017). The species is potential as ornamental potted plant.
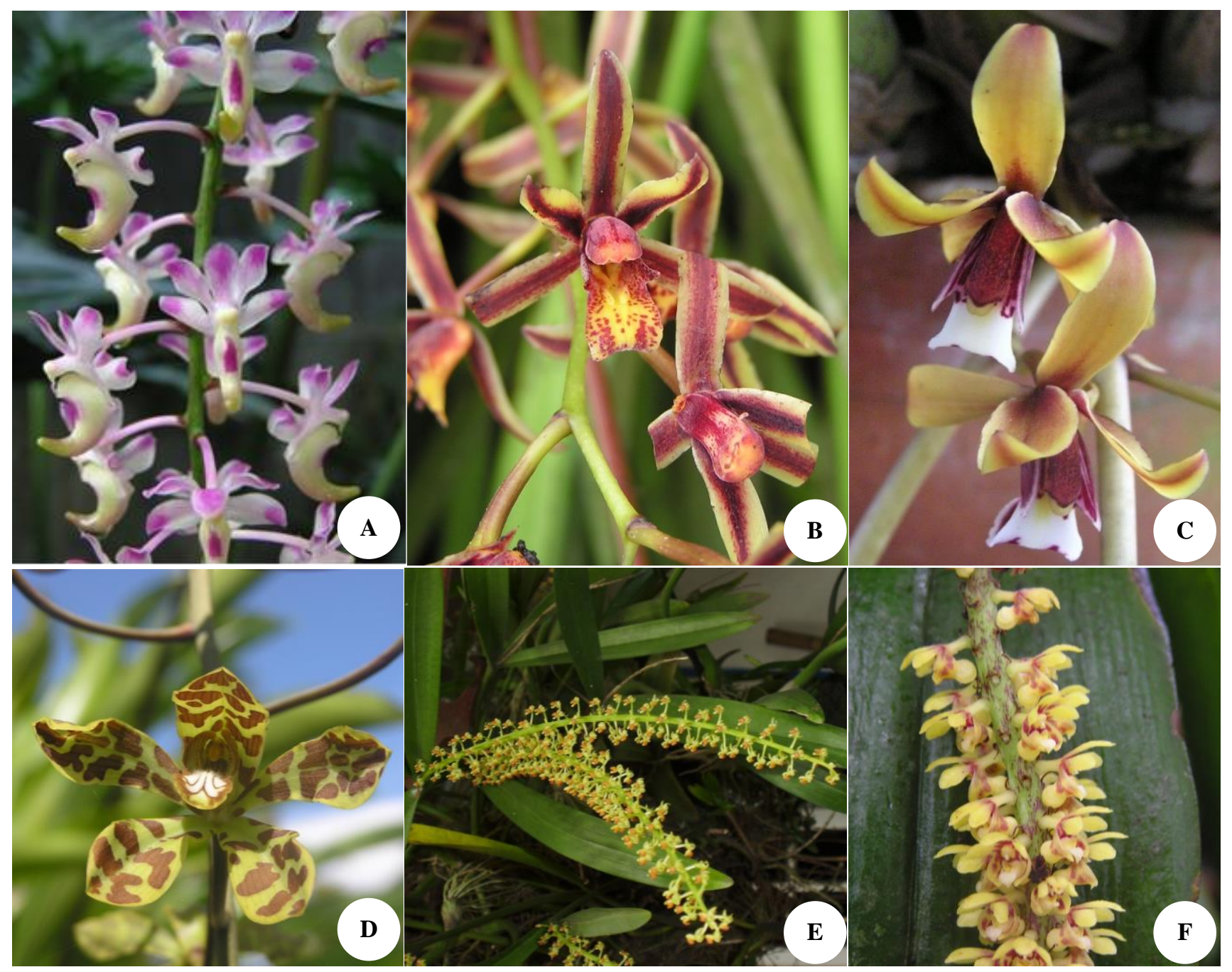

Figure 3. Epiphytic orchids of Tanjung Peropa Wildlife Reserve, Southeast Sulawesi, Indonesia. A. Aerides odorata, B. Cymbidium bicolor, C. Cymbidium finlaysonianum, D. Grammatophyllum scriptum, E. Liparis condylobulbon, F. Pomatocalpa spicatum 


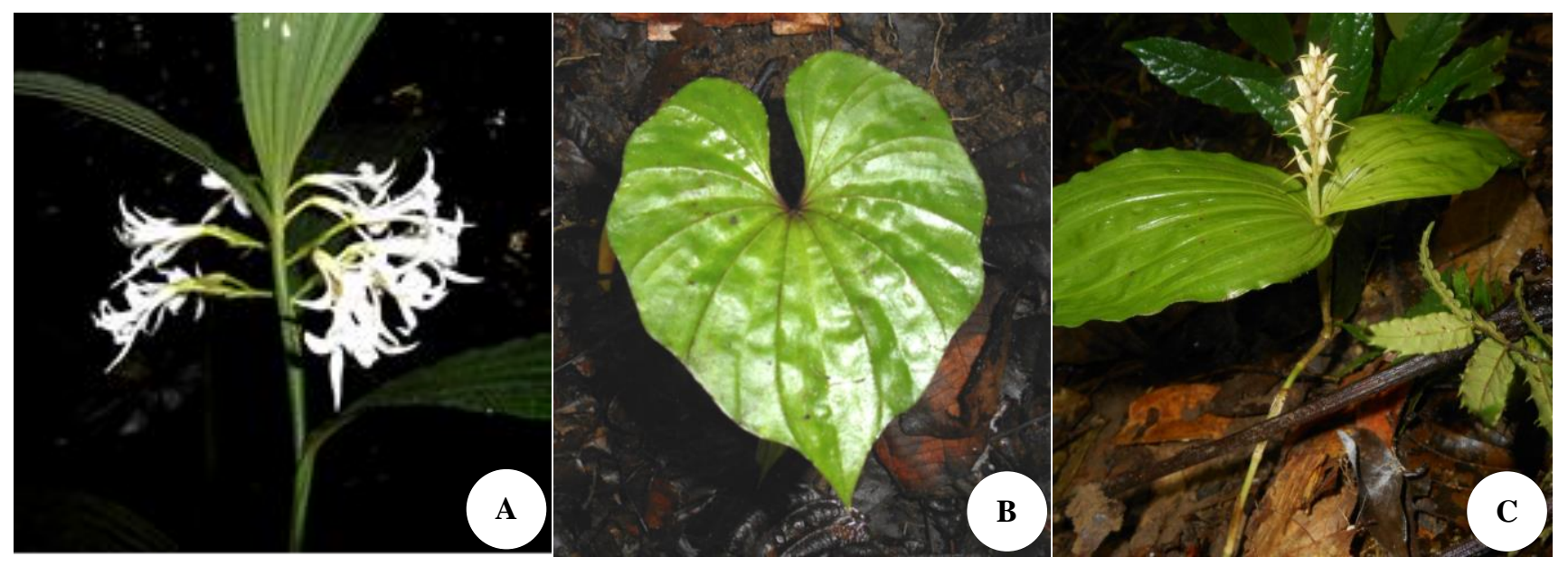

Figure 4. Terrestrial orchids of Tanjung Peropa Wildlife Reserve, Southeast Sulawesi, Indonesia. A. Corymborkis veratrifolia, B. Nervilia concolor, C. Tropidia angulosa

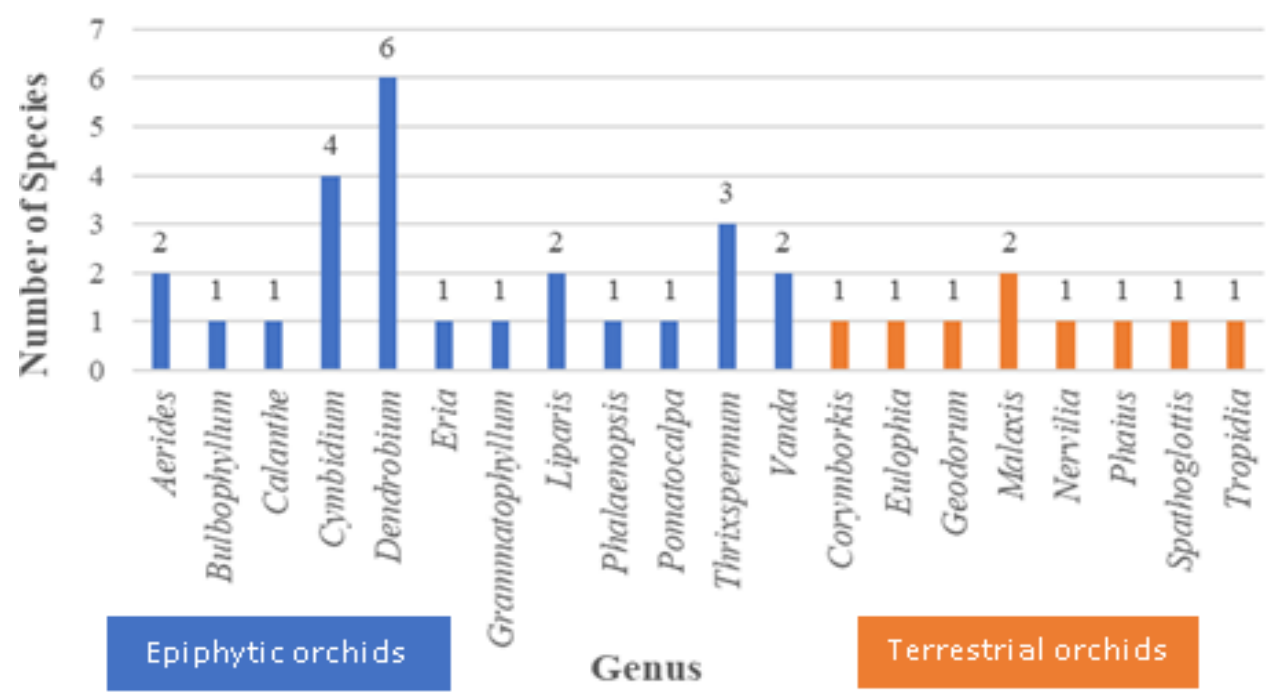

Figure 5. Number of orchid species collection in Kendari Botanic Gardens, Southeast Sulawesi, Indonesia

Only one species of Eulophia found in Tanjung Peropa forest, namely E. spectabilis, it was located at Amolengu and Ulunesse Villages (Table 1). This species has wide distribution, ranging from India, Myanmar, Sri Lanka, China, SE Asia, Papua New Guinea up to Solomon Islands (Seidenfaden and Wood 1992). It can be found from sea level to about $900 \mathrm{~m}$ asl. In research sites, E. spectabilis was found in the open area, it has white to brown, $5-7 \mathrm{~cm}$ wide corms, 2-3 narrowly lanceolate leaves. This species has long inflorescence which arises from near the base of corm, racemose, $40-50 \mathrm{~cm}$ tall, bearing 10-20 flower buds with pure white-red petals and dull-brownish olive sepals. Half of the inflorescence can bloom uniformly but not fully open. The corm of this species has medicinal value and is well known in India for various health treatments such as arthritis and knee pain (Jalal et al. 2014).

Tropidia angulosa (Figure 4.C) was one of the terrestrial orchid found in the humid soil and dense canopy coverage area, and in Bantimurung Bulusaraung National Park, this species found in a bit dark place (Puspitaningtyas 2017). Since the plant size is small (15-20 cm height) and it does not have pseudobulbs or any storage organ, then it takes extra care in collecting the plant without damaging its roots. The stem always bears two leaves at the top. Leaves are plicates with terminal inflorescence between two leaves. Based on Comber (1990), this species has wide distribution from India, Burma, Malaysia, Sumatra, to Java, but now it is reported existing in Sulawesi (Puspitaningtyas 2017).

\section{Ex-situ conservation in Kendari Botanic Gardens}

The orchid specimens from Tanjung Peropa WR could grow well in the paranet house (for epiphytic orchid) and plastic house (for terrestrial orchid). Soil conditions in Tanjung Peropa WR and Kendari BG are quite similar. 
Meanwhile, the epiphytic orchid is not affected by soil, but affected by the environment of Kendari BG, including topography. Topography condition in Kendari BG is dominated by slope and rocky hill with 90-275 m asl and the slope varies between $0-90^{\circ}$. This environment supports adaptation and acclimatization of orchid which were taken from the forests.

Kendari Botanic Gardens has conducted two exploration activities in SE Sulawesi, they were in Muna Island (2017) and Tanjung Peropa WR (2019). From those two places, Kendari BG has collected 34 species of orchid, 25 species of epiphyte, and 9 species of terrestrial orchids based on the registration data, (Figure 5). This number is still limited comparing with the number of orchid species recorded in Sulawesi (548 species) based on Thomas and Schuiteman (2002) or Kendari BG has only collected 6,2\% of existing orchid in Sulawesi. Thus, exploring and collecting the orchid around SE Sulawesi in order to enrich orchid collection in Kendari BG are still needed.

In conclusion, the results of the study recorded approximately 15 species of orchids found in Tanjung Peropa Wildlife Reserve. These were representative of 12 genera, which consisted of 10 species of epiphytic orchids and five species of terrestrial orchids. Most orchids found in this area are lowland orchid which is very common growing in Sulawesi. The unique orchid species found in this area are Aerides odorata, Grammatophyllum scriptum dan Tropidia angulosa. All those orchids have to be conserved, both in situ and ex situ conservation. Kendari BG has collected 34 species of orchid and needs more exploration activities to save plant diversity by ex situ conservation.

\section{ACKNOWLEDGEMENTS}

The authors would like to acknowledge the Research Center for Plant Conservation and Botanic Gardens- LIPI, Kendari Botanic Gardens, Nature Conservation Agency of Southeast Sulawesi, local people around Tanjung Peropa Wildlife Reserves, exploration team (Maman Suratman, Daden Sukarta, Mukti Agung, and Abdul Gafar), and also field guides (Sahidin, Sultan, Daeng, Latie, Kadir dan Isnan) who supported the flora exploration in Southeast Sulawesi.

\section{REFERENCES}

Comber JB. 1990. Orchids of Java. Bentham-moxon Trust. Royal Botanic Garden, Kew.

Comber JB. 2001. Orchids of Sumatra. The Royal Botanic Gardens, Kew.

Febrianti E, Astuti AN. 2019. The reflection of Kendari Botanical Gardens Development. UPTD Kebun Raya Kendari Dinas Lingkungan Hidup dan Kehutanan Kota Kendari bekerjasama dengan Pusat Penelitian Konservasi Tumbuhan dan Kebun Raya-LIPI, Kementerian PUPR, dan Pemerintah Kota Kendari. [Indonesian]

Handoyo P, Prasetya R. 2012. Orchids of Sulawesi. Perhimpunan Anggrek Indonesia, Jakarta. [Indonesian]
Hidayat S, Puspitaningtyas DM, Hartini S, Munawaroh E, Astuti IP, Wawangningrum H. 2017. Flora Exploration: 25 Years Exploring Jungle of the Indonesian Archipelago. LIPI Press, Jakarta. [Indonesian]

Indonesian Forest. 2015. Tanjung Peropa Wildlife Reserves, Southeast Sulawesi. http://forestid.blogspot.com/2015/11/suaka-margasatwatanjung-peropa.html. [Indonesian]

Indrawati, Yusuf S, Hariani. 2017. Morphology characterization of wild orchid (Orchidaceae) of Rawa Aopa Watumohai National Park, the collection of Halu Oleo University Botanical Garden. Biowallacea 4 (2): 645-654. [Indonesian]

Jalal JS, Jayanthi J, Kumar P. 2014. Eulophia spectabilis: A high-value medicinal orchid under immense threat due to overexploitation for medicinal uses in Western Ghats, Maharashtra, India. MIOS J 15 (10): 9-15.

Katta J, Rampilla V, Khasim SM. 2019. A study on phytochemical and anticancer activities of epiphytic orchid Aerides odorata. Eur J Med Plants 28 (3): 1-21.

Lawler JL. 1984. Ethnobiology of the Orchidaceae. In: Arditti (ed) Orchid Biology Reviews and Perspective III. Comstock Publishing.

Lestari DA, Santoso W. 2011. Inventory and habitat study of orchids species in Lamedai Nature Reserve, Kolaka, Southeast Sulawesi. Biodiversitas 12 (1): 28-33.

Mustari AH. 2017. The checklist of plant species in Southeast Sulawesi in Tolaki local language. IPB Press. [Indonesian]

O'Byrne P. 1994. Lowland Orchids of Papua New Guinea. SNP Publishers, Singapore.

Purnomo DW, Magandhi M, Kuswantoro F, Risna RA, Witono JR. 2015. Development of collections of regional botanical garden plants within the framework of Indonesian plant conservation strategies. Bot Gard Bull 18 (2): 111-124.

Puspitaningtyas DM. 2019. Inventory of orchids in Polewali Mandar, West Sulawesi, Indonesia. Biodiversitas 20 (7): 1887-1896.

Puspitaningtyas DM. 2017. Orchid inventory in BantimurungBulusaraung National Park, South Sulawesi, Indonesia. Biodiversitas 18 (1): 341-350.

P2KTKR. 2018. The Progress Report of Local Botanical Gardens Development in Indonesia. P2KTKR. [Indonesian]

Rahayu EMD, Putri WU. 2019. Inventarisation of orchid diversity and epiphytic orchid vertical distribution in Bantimurung Bulusaraung National Park. Buletin Kebun Raya 22 (2): 131-142. [Indonesian]

Ram AT, Shamina M, Pradeep AK. 2015. Dendrobium crumenatum (Orchidaceae): A new record for mainland India. Rheedea 25 (1): 6971.

Seidenfaden G, Wood JJ. 1992. The Orchids of Peninsular Malaysia and Singapore (A Revision of R.E Holttum: Orchids of Malaya). Olsen \& Olsen, Fredensborg, Denmark.

Sharma S, Kumar R, Singh SK, Jalal JS. 2013. Nervilia punctata (Orchidaceae) - A new record for Northeast India. Richardiana 14: 32-38.

Sulistiarini D. 2008. Orchid species diversity of Wawonii Island. Berkala Penelitian Hayati 14: 21-27.

Sulistiarini D, Potter D, O’Byrne P. 2017. Dendrobium tinukariensis, a new species of section Calyptrochilus from the Mekongga Mountains, Southeast Sulawesi, Indonesia. Reinwardtia 16 (2): 103-106.

Sulistiarini D, Mahyar UW. 2003. Orchid Species of Wartabone National Park. Pusat Penelitian Biologi. [Indonesian]

The Plant List. 2013. The Plant List, A Working List of All Plant Species Version 1.1. http://www.theplantlist.org/

Thomas S, Schuiteman S. 2002. Orchids of Sulawesi and Maluku: A preliminary Catalogue. Lindleyana 17 (1): 1-72.

Vermeulen J, O’Byne P. 2011. Bulbophyllum of Sulawesi. Natural History Publications, Kota Kinabalu.

Watthana S, Pedersen HA. 2006. Substrate diversity, demography, and fruit set in two populations of the epiphyte Pomatocalpa spicatum (Orchidaceae) in Thailand. Selbyana 27 (2): 165-174.

Whitten AJ, Mustafa M, Henderson GS. 2002. The Ecology of Sulawesi. $2^{\text {nd }}$ ed. The Ecology of Indonesia Series. Periplus Editions, Hongkong

Widyatmoko D, Risna RA. 2017. A role of Indonesian botanic gardens in achieving global strategy for plant conservation goals. Ann Mo Bot Gard 102: 377-385. 